Proc. Estonian Acad. Sci. Geol., 2001, 50, 4, 233-253

\title{
NEW DATA ON THE DISTRIBUTION AND STRATIGRAPHY OF THE BOTTOM DEPOSITS OF LAKE PEIPSI, EASTERN ESTONIA
}

\author{
Tiit HANG ${ }^{\mathrm{a}, \mathrm{b}}$, Avo MIIDEL ${ }^{\mathrm{c}}$, Volli KALM ${ }^{\mathrm{d}}$, and Kai KIMMEL ${ }^{\mathrm{b}, \mathrm{e}}$ \\ ${ }^{a}$ Institute of Physical Geography and Quaternary Geology, Stockholm University, S 10691 \\ Stockholm, Sweden; Tiit.Hang@geo.su.se \\ ${ }^{\mathrm{b}}$ Institute of Geography, University of Tartu, Vanemuise 46, 51014 Tartu, Estonia \\ c Institute of Geology, Tallinn Technical University, Estonia pst. 7, 10143 Tallinn, Estonia \\ d Institute of Geology, University of Tartu, Vanemuise 46, 51014 Tartu, Estonia \\ e Endla Nature Reserve, Tooma 48401, Jõgeva County, Estonia
}

Received 23 May 2001, in revised form 4 September 2001

\begin{abstract}
The bottom sediments of Lake Peipsi, eastern Estonia, were investigated. Earlier obtained continuous seismic reflection profiling data is compared with the coring data. Generally good accordance is found, with minor discrepancies in the southern part of the investigated area. A map of the distribution and thickness of Holocene organic lake deposits is presented. Water level during the Lake Small Peipsi stage at the end of the Younger Dryas was at least $10 \mathrm{~m}$ lower than at present (30 $\mathrm{m}$ a.s.1.), as recorded from the sediment record and pollen analyses. The Preboreal Lake Peipsi is characterized by the accumulation of calcareous deposits, ostracod evidence in which point to a shallow and cold body of water with a slow lake level rise.
\end{abstract}

Key words: Late Weichselian, Lake Peipsi, lake level changes, lithology, Pandivere-Neva ice marginal formations, pollen stratigraphy.

\section{INTRODUCTION}

Lake Peipsi (Fig. 1), with its surface area of $3555 \mathrm{~km}^{2}$, is the fourth largest inland body of water in Europe after Ladoga $\left(18135 \mathrm{~km}^{2}\right)$ and Onega $\left(9700 \mathrm{~km}^{2}\right)$ in Russia and Vänern $\left(5650 \mathrm{~km}^{2}\right)$ in Sweden. The submeridionally elongated lake measures approximately $150 \mathrm{~km}$ in length and $23-42 \mathrm{~km}$ in width. Its catchment area $\left(47800 \mathrm{~km}^{2}\right)$ is shared between Estonia, Russia, and Latvia. The lake is drained into the Gulf of Finland via the $77 \mathrm{~km}$ long Narva River.

Lake Peipsi is a shallow body of water (Fig. 1) with the mean water depth of about $8 \mathrm{~m}$ ( $\max 15 \mathrm{~m})$. It consists of three parts (from north to south): L. Peipsi (s.s.), L. Lämmijärv, and L. Pihkva. In our paper only the biggest, northernmost part - Lake Peipsi - is considered (Fig. 1). 


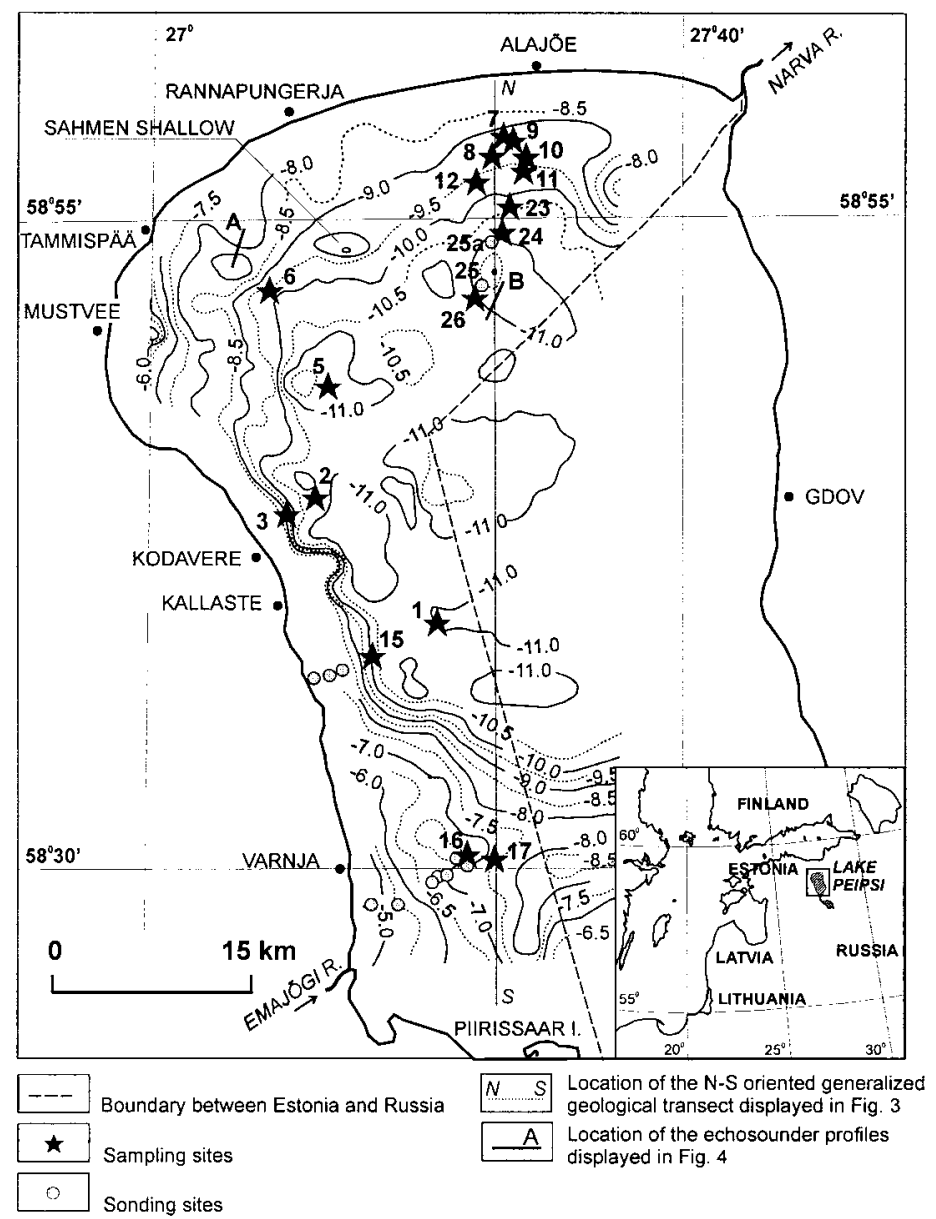

Fig. 1. Location of the investigated part of Lake Peipsi and bathymetry map modified from Noormets et al. 1998

Despite long-term and interdisciplinary investigations, very little is known about the bottom deposits of L. Peipsi. Surface deposits, sampled with gripscoop, have been studied over the entire lake bottom (Raukas \& Rähni 1981; Raukas 1981; Pirrus 1981). For applied purposes, the sandy deposits in water depths of 1-2.5 m, 0.1-1.5 km offshore from the north and west coasts and in the surroundings of Piirissaar Island, have been mapped (Valt 1976; Hang \& Miidel 1999a). The only deep borehole, in which the thickness of Quaternary deposits was $27.3 \mathrm{~m}$ (Kajak 1964), is situated on the Sahmen Shallow (Fig. 1). The first information on the thickness, structure, and distribution of the Quaternary deposits in the lake itself was recently obtained through the continuous seismic reflection profiling in the western part of the lake (Noormets et al. 1998). 
The aim of the present study was to strengthen the seismic interpretations and to contribute to the knowledge about the character and distribution of the bottom deposits as well as about the Late Weichselian and Early Holocene development of L. Peipsi. Tiit Hang and Volli Kalm carried out the fieldwork and provided the lithostratigraphical description and analysis. Tiit Hang and Avo Miidel are responsible for the comparison of the lithostratigraphical and seismic data, Kai Kimmel for the pollen data. Interpretation of the results, discussion, and conclusions were contributed by Tiit Hang, Avo Miidel, and Volli Kalm.

\section{GEOLOGICAL SETTINGS}

The following description of the geological structure of the lake depression is mainly based on the results of continuous seismic reflection profiling (Noormets et al. 1998; Miidel et al. 2001).

\section{Bedrock topography}

The basin of L. Peipsi is a glacially eroded bedrock depression in Ordovician and Devonian rocks with transitional boundaries. The rather flat bedrock topography under the lake itself was discovered through seismic investigations (Miidel et al. 2001). The surface tends to lower towards the central part (Fig. 2A). In the meridional direction, the inclination is bigger in the northern part of the lake. From west to east, the bedrock surface descends often very abruptly (Fig. 2A).

A wedge-shaped, north-south trending eminence, narrowing and lowering (from 15 to $25 \mathrm{~m}$ below lake level (b.1.1.)) in a southerly direction, starts from the north coast. West of it there occurs an up to $7 \mathrm{~km}$ wide trough (at depths from 29 to $52 \mathrm{~m}$ b.1.1.) (Fig. 2A). The bottom of the central depression is c. $60 \mathrm{~m} \mathrm{b.1.1}$. South of the central depression, the uprising bedrock forms a plateau of Devonian terrigenous rocks with the surface lying between 30 and $40 \mathrm{~m}$ b.1.1. (Fig. 2A).

\section{Quaternary cover}

The highly variable thickness of Quaternary deposits is in good accordance with the bedrock topography. It increases from the surrounding bedrock elevations towards the central part of the lake basin, being usually between 5 and $10 \mathrm{~m}$ and reaching $45 \mathrm{~m}$ in the central part of the lake (Noormets et al. 1998). Along the west coast of the lake, the thickness of Quaternary deposits increases rapidly from $10-15$ to $30 \mathrm{~m}$; in the southern part of the lake it still remains around $30 \mathrm{~m}$.

In the course of the continuous seismic reflection profiling, two seismic units were distinguished in the Quaternary cover (Noormets et al. 1998). The lower one consists of till and the upper of the glaciolacustrine and postglacial lacustrine 

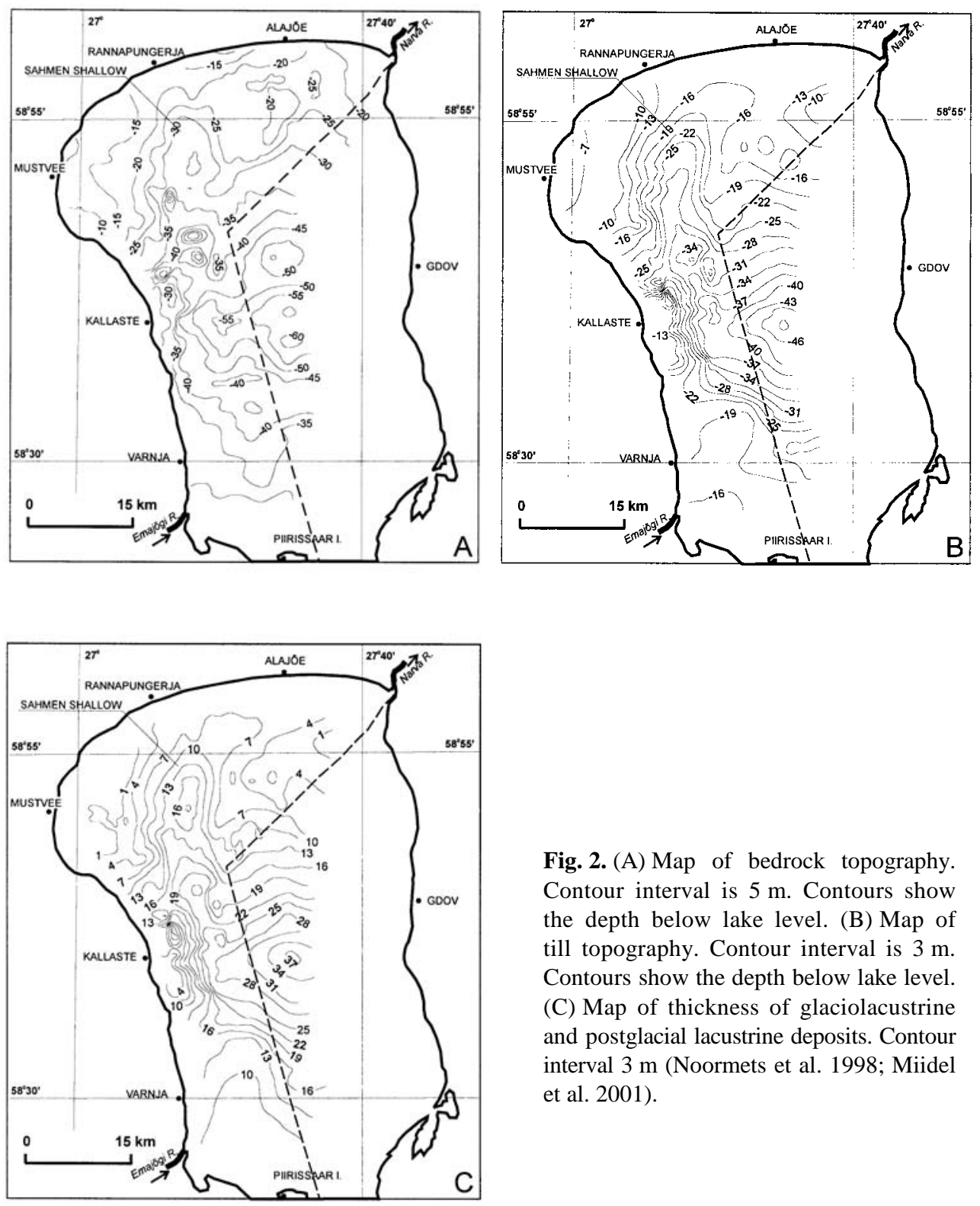

Fig. 2. (A) Map of bedrock topography. Contour interval is $5 \mathrm{~m}$. Contours show the depth below lake level. (B) Map of till topography. Contour interval is $3 \mathrm{~m}$. Contours show the depth below lake level. (C) Map of thickness of glaciolacustrine and postglacial lacustrine deposits. Contour interval $3 \mathrm{~m}$ (Noormets et al. 1998; Miidel et al. 2001).

deposits. The till is somewhat thicker in the southern and central parts of the lake $(10-20 \mathrm{~m})$ as compared to the northern and northwestern parts $(5-10 \mathrm{~m})$, being thickest $(33 \mathrm{~m})$ in the central part, where the mentioned trough-like depression occurs in the bedrock topography (Fig. 2A). The upper surface of the till is rather flat (Fig. 2B). It is located at 7-10 m b.l.1. in the northwestern part, deepening gradually down to $50 \mathrm{~m}$ b.1.1. in the central part, and rising again to $16 \mathrm{~m}$ b.l.1. in the southern part of the lake (Fig. 2B). 
The thickness of glaciolacustrine and postglacial lacustrine deposits, directly overlying the till, varies over a wide range from 0 to $37 \mathrm{~m}$ (Fig. 2C). These deposits are locally absent in the northwestern and northeastern parts of the seismically investigated area. Where present, they are generally rather thin, less than $10 \mathrm{~m}$ in the northern part of the lake, but may reach $18 \mathrm{~m}$ along the local bedrock depressions and about $37 \mathrm{~m}$ in the central part of the lake (Fig. 2C) (Noormets et al. 1998).

\section{METHODS}

Coring of bottom deposits was performed through the lake ice cover in a number of sites (Fig. 1). A Russian peat corer with a $1 \mathrm{~m}$ long and $75 \mathrm{~mm}$ diameter chamber as well as a piston corer with $1.5 \mathrm{~m}$ tubes were used to obtain samples. Samples were packed into PVC tubes for the transport and subsampled in the laboratory. Coring sites were positioned by the satellite-based Global Positioning System (GPS). During the fieldwork, the GPS had an accuracy of approximately $\pm 20 \mathrm{~m}$.

Both, the seismic and coring data were used in constructing a generalized north-south oriented geological transect (Figs. 1, 3) as well as the chart of the distribution and thickness of the Holocene gyttja and calcareous deposits. The sediment core Pe-2 was subsampled for pollen analysis at $5 \mathrm{~cm}$ intervals close to the Pleistocene/Holocene boundary; rest of the core was subsampled with a varying step. Material for pollen analysis was prepared following the standard laboratory technique: boiling in $\mathrm{KOH}$, sieving with a $0.5 \mathrm{~mm}$ sieve, and acetolysis, as described by Berglund \& Ralska-Jasiewiczowa (1986). The samples rich in minerogenic material were additionally treated by density separation with heavy liquid $\left(\mathrm{CdJ}_{2}+\mathrm{KJ}\right)$. The pollen diagram was designed with the TILIA program (Grimm 1992).

Spacing of samples for lithological analysis from the sediment core Pe-2 was $35 \mathrm{~cm}$. The grain-size composition was determined using sieving and pipette analysis. The organic content was estimated as loss-on-ignition after heating at $500^{\circ} \mathrm{C}$ for $2 \mathrm{~h}$. The carbonate content was estimated by the "weight-loss" method after Blakemore et al. (1987).

\section{RESULTS \\ Lithostratigraphy}

The brownish loamy till, underlying Late Weichselian and Holocene deposits, has been reached only in a few sites close to the west coast (site 3) of the lake and 11 to $15 \mathrm{~km}$ offshore from Alajõe (sites 23-25, Fig. 1). As it was not possible to penetrate through the whole portion of the Holocene and late-glacial sediments in the middle of the lake, the till topography there, with its minimum altitudes around $40-46 \mathrm{~m}$ b.1.1. (Fig. 2B), should be taken as it stands from the seismic interpretations (Noormets et al. 1998). 


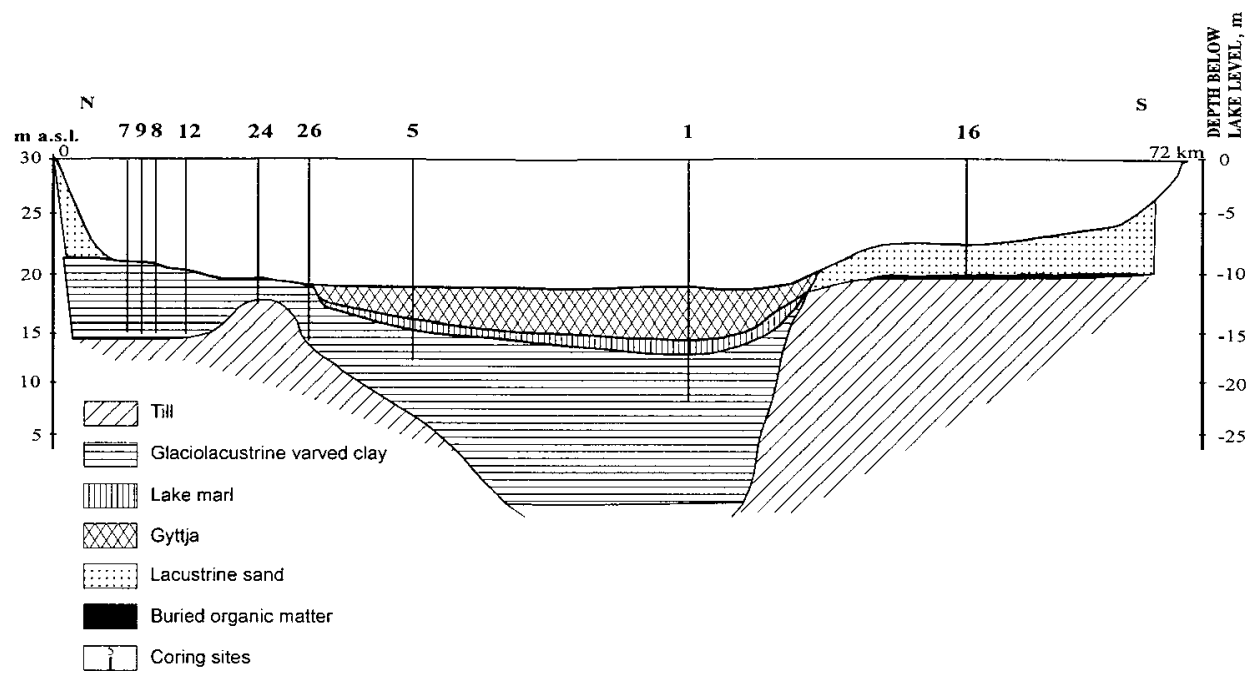

Fig. 3. North-south oriented generalized cross-section of Lake Peipsi. See Fig. 1 for the location of the cross-section and the coring sites.

On the north-south oriented profile (Fig. 3), the till surface is elevating between coring sites 12 and 26. Scattered geological record of the till outcropping in the surface layer in adjoining the coring sites shallow water areas (Sahmen Shallow), northeast of coring sites $23-26$, as well as close to the outlet to the Narva River, allow us to suggest the existence of a low, southwest-northeast oriented ridge-like elevation. This is supported by the seismic data where the higher altitudes in till topography close to the areas mentioned above are recorded. The height of the ridge recorded through the corings is 5-6 m. It is probably changing up to 10-11 m, while the altitude of the till surface on the Sahmen Shallow $(20.3 \mathrm{~m})$ and close to the Narva River outlet (21-23 m) is higher than the crest of the till ridge $(\mathrm{c} .17 \mathrm{~m})$ close to our coring sites. The width of the ridge from the foot is about $7 \mathrm{~km}$ and from the crest c. $6 \mathrm{~km}$. On the echosounder profile crossing the ridge west of the Sahmen Shallow (Fig. 4), even two elevations with a depression in between could be followed. There are no clear morphological signs of continuation of the ridge in the adjoining coastal areas, but west of the Sahmen Shallow, between Mustvee and Tammispää, till is outcropping in the bottom of the lake and on the coast.

Till, which is outcropping in the coastal area near Varnja (southern part of the investigated area) (Fig. 5), was also discovered 1-1.5 km offshore under a c. $1 \mathrm{~m}$ sand cover. About $10 \mathrm{~km}$ offshore (sites 16, 17 in Fig. 1) we could not reach the till lying below a c. $2 \mathrm{~m}$ thick sand cover. Therefore, the occurrence of heavily compact substratum, most likely till, was suggested.

In the northern and central parts of the lake the thickness of glaciolacustrine varved clays covering the till reaches up to $37 \mathrm{~m}$ (Fig. 2C). In the northern part, 

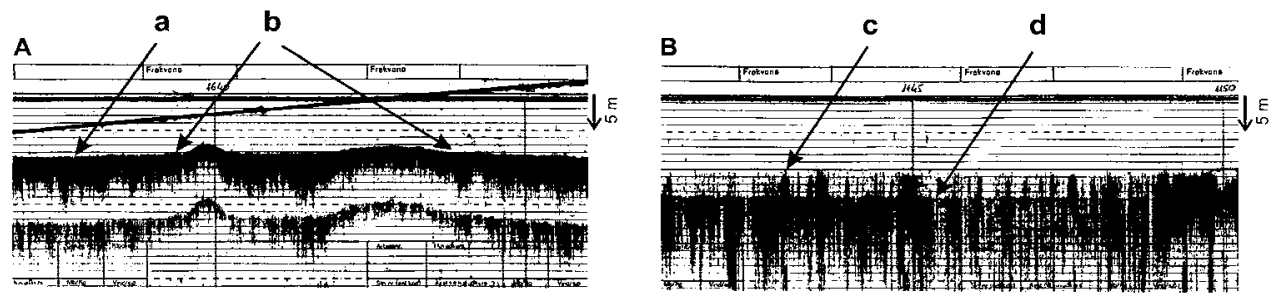

Fig. 4. Examples of echosounder profiles. (A) Example of clear reflection from the bottom of the lake at water depths from 7 to $9 \mathrm{~m}$ : a, distinct reflector from the bottom representing the surface of glaciolacustrine deposits west of the Sahmen Shallow; b, till ridge buried under the glaciolacustrine varved clay west of the Sahmen Shallow. (B) Example of unstable reflector from the bottom at a water depth of about $10 \mathrm{~m}: \mathrm{c}$, weak reflector from the bottom representing the surface of postglacial organic lake deposits; d, surface of the glaciolacustrine deposits. See Fig. 1 for the location of profiles.

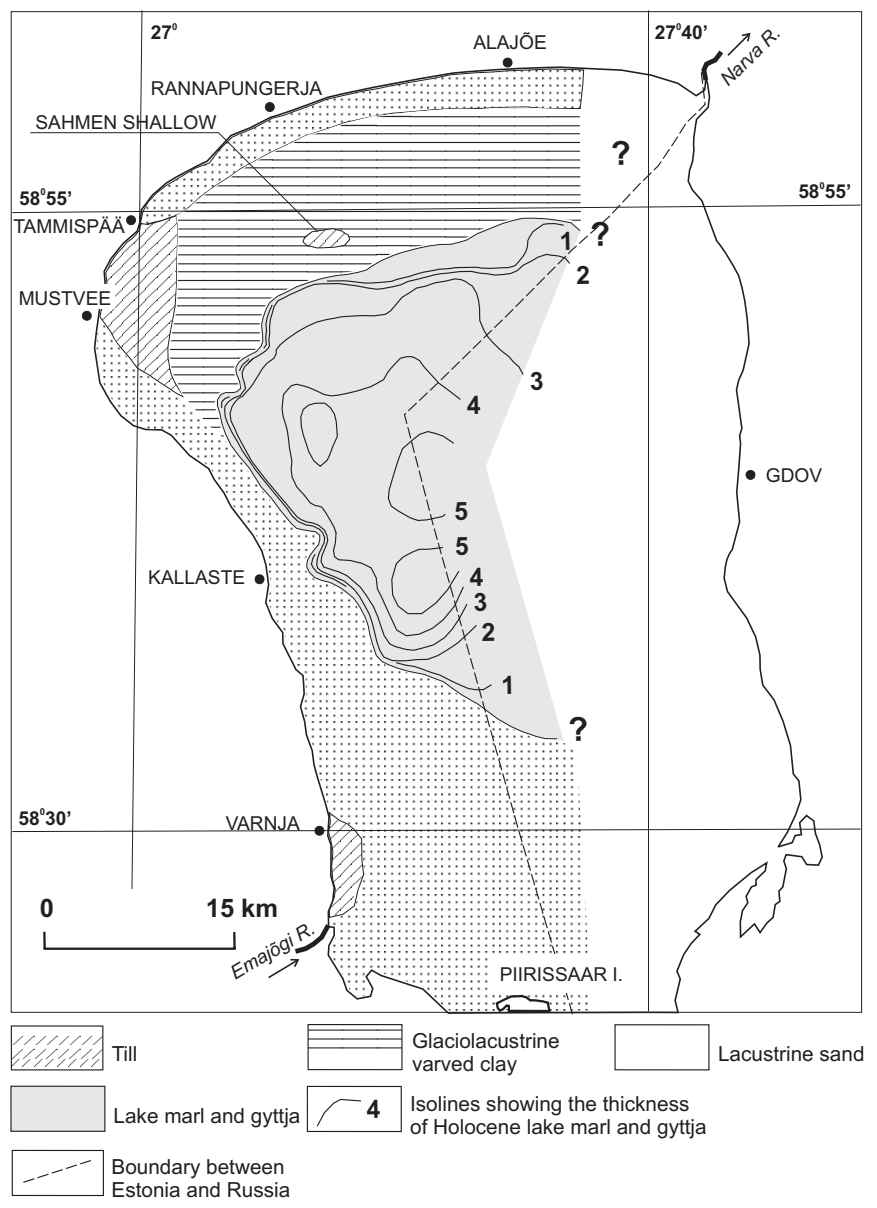

Fig. 5. Map of bottom deposits of Lake Peipsi. 
the mean $7 \mathrm{~m}$ thickness of the clay is in good accordance with the seismic interpretations. The clay is somewhat thinner $(1.5-3 \mathrm{~m})$ only on top of the west-east oriented till ridge (Fig. 3). Very distinct varves are easy to correlate between the sequences and are currently connected to the chronology covering c. 370 years. Very thin varves with a changing thickness and grain-size of the material in the upper portion of the varved clay are present only in few sites. In most cases in the northern part of the lake, the upper surface of the varved clay seems to be erosional and only partly covered with a thin $(5-50 \mathrm{~cm})$ layer of Holocene organic lake deposits.

In the deeper part of the lake (sites 1, 2, 5 in Fig. 1), we could not penetrate the portion of the Holocene and glaciolacustrine sediments. Both varved and homogenous clay were reached from the glaciolacustrine part. It should be mentioned that the layers of homogenous clay were common also within the varved sequences in the northern part of the lake. There they were interpreted as synsedimentary slides, while the varves from below and upon the "slides" were easily correlated with the ones from continuous sequences. The idea of syn- or postsedimentary slides is also supported by the appearance of homogenous clay on different, non-correlatable stratigraphical levels (Fig. 6).

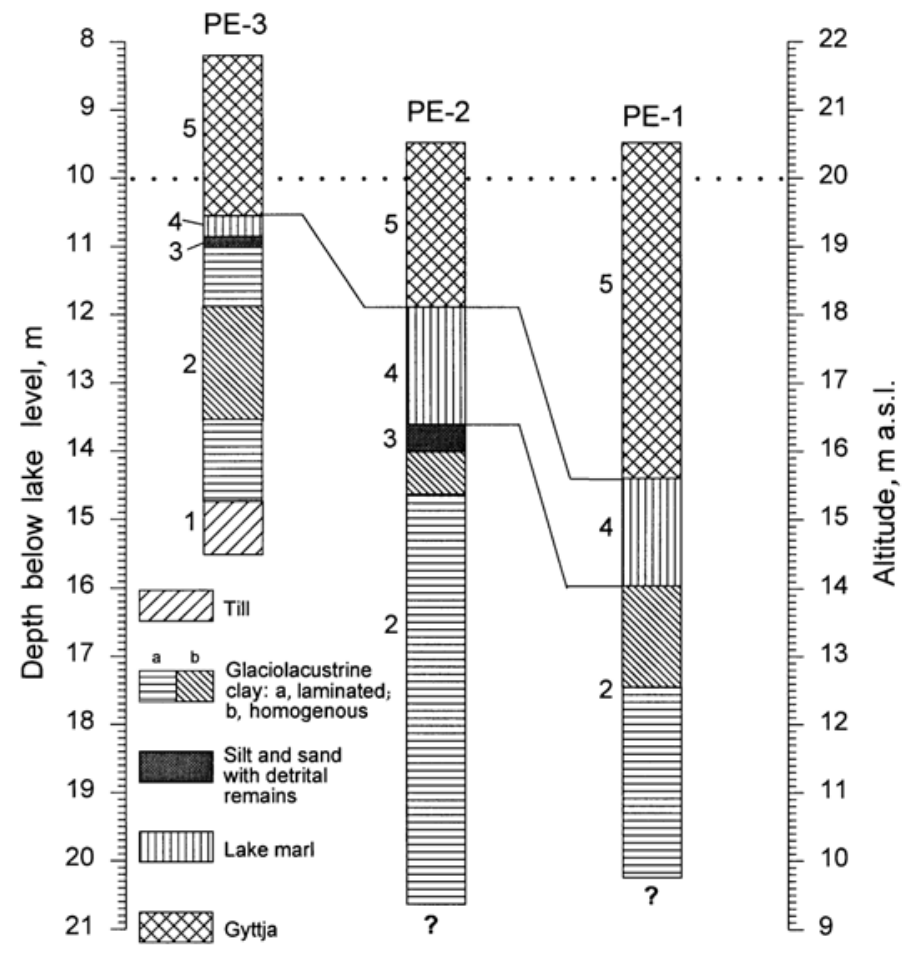

Fig. 6. Lithology of the sequences Pe-1, Pe-2, and Pe-3 with the lithostratigraphical units (1-5) described in Table 1. See Fig. 1 for the location of the sites. Dotted line marks the possible level of Lake Small Peipsi. 
Varved sequences from the central part of the lake (sites 1,2,5) were different from those in the northern L. Peipsi area. Varves of variable thickness and grainsize of the material, with ripples and lenses were common. The boundaries between the layers were unclear and counting of varves appeared unconvincing.

On the seismic profiles from the central, deeper part of the lake, an unstable reflector appears on top of the signal interpreted as glaciolacustrine deposits (Fig. 4) (Noormets et al. 1998). This layer has been identified as Holocene organic lake deposits. Supported by the corings, echosounder profiles prove that the distribution of the Holocene organic lake deposits is limited to the deeper (from c. $9 \mathrm{~m}$ of the water depth), central part of the lake (Figs. 3, 5). In shallower areas, where the reflection from the bottom was distinct (Fig. 4), these deposits are absent or represented by a very thin (a few centimetres thick) cover of loose gyttja. The corings revealed that the sediment package described consisted actually of two different types of sediments (Fig. 3, Table 1). The lower one, lying on top of glaciolacustrine clay, is lake marl, covered by gyttja. The sediment stratigraphy of three sequences (Fig. 6) from different parts of the lake is described in Table 1. Some lithological characteristics of the sequence Pe-2 are presented in Fig. 7.

Transition from the glaciolacustrine clays (unit 2) to Holocene lake deposits is very distinct, being erosional in areas closer to the coast (sites 2, 3). The transition is marked with sandy silt (Pe-2, unit 3) or a fine-grained sand layer (Pe-3, unit 3) rich in organic remains (Fig. 6). The remains of bivalves Pisidium amnicum (O. F. Müller 1774) and two species of snails, Valvat profunda (Clessin 1887) and Valvata depressa (Pfeiffer 1828), were identified by A. Järvekülg. All these species are wide-spread in European freshwater lakes and rivers. In the lakes they prefer fine-grained bottom deposits or aquatic plants in the upper littoral zone (water depth less than $10 \mathrm{~m}$ ) with hard water. More precise determination of the environmental conditions is complicated due to the wide range of ecological thresholds for the mentioned species. The upper transitional boundary of the mentioned sandy silt or sand layer is characterized by an increased content of $\mathrm{CaCO}_{3}$ and detrital remains (Fig. 7, Table 1). The sand and silt are likely the shallow water offshore facies and have remained from the period of considerably lower water level. In the deeper part of the lake (sites $1,5,15)$ the boundary between glacial clay and Holocene deposits is more gradual than previously described. In the sequence Pe-1, the uppermost portion of glaciolacustrine deposits is represented by homogenous silt (unit 2 in Fig. 6), the upper boundary of which is distinct and characterized by the increased content of sand and detrital remains. It is most likely that during the low-water period, when in the areas closer to the present coast (sites 2 and 3 ) erosional conditions prevailed, marked with a sandy silt layer (unit 3, Fig. 6), the accumulation of homogenous silt continued in the central part of the lake (site 1). Probably, silt and sand particles reached the deeper part through the wave wash in coastal areas.

This thin layer of silt or sandy deposits (unit 3, Fig. 6) is covered by calcareous deposits, varying in thickness from a couple of centimetres to almost $2 \mathrm{~m}$ (site 2) 
Table 1. Lithostratigraphic subdivision of three sediment sequences from Lake Peipsi

\begin{tabular}{|c|c|c|}
\hline $\begin{array}{l}\text { Depth below } \\
\text { lake level, } \mathrm{m}\end{array}$ & $\begin{array}{l}\text { Unit } \\
\text { No. }\end{array}$ & Description \\
\hline \multicolumn{3}{|l|}{ Pe-1 } \\
\hline $0.00-9.50$ & & Water \\
\hline $9.50-14.40$ & 5 & $\begin{array}{l}\text { Gyttja: uppermost part dark brown to black, from c. } 12.90 \mathrm{~m} \text { colour changes } \\
\text { to greenish grey, lower boundary is gradual }(14.20-14.40 \mathrm{~m})\end{array}$ \\
\hline $14.40-15.95$ & 4 & Lake marl: homogenous, light bluish-grey with detritus \\
\hline $15.95-20.23$ & 2 & $\begin{array}{l}\text { Glaciolacustrine deposits: } 15.95-17.00 \mathrm{~m} \text { homogenous, reddish-brown } \\
\text { sandy silt, } 17.00-17.45 \mathrm{~m} \text { light brown silt with thin chemical lamination } \\
\text { in the lower portion, } 17.45-20.23 \mathrm{~m} \text { brownish varved clay, thickness of } \\
\text { varves varies from a couple of millimetres to some centimetres, summer } \\
\text { layers consist mainly of coarse silt or fine sand, ripples are common, winter } \\
\text { layers consist of reddish-brown homogenous clay }\end{array}$ \\
\hline
\end{tabular}

Pe-2

0.00-9.50 Water

9.50-12.00 5 Gyttja: dark brown to black (9.50-10.00 m), lower portion (10.00-12.00 m) greenish-grey; according to $\mathrm{CaCO}_{3}$ and organic content the interval could be divided into calcareous silicic gyttja $(9.50-11.00 \mathrm{~m})$ and silicic gyttja (11.00-12.00 m), transition from gyttja to lake marl gradual

12.00-13.60 4 Lake marl: homogenous, light bluish-grey, content of sand particles changing from 5 to $25 \%$, clay content is increasing (from 35 to $50 \%$ ) towards the upper boundary of the interval

13.60-14.02 3 Sandy silt: brownish-grey, lower boundary very sharp, transition to lake marl (13.85-13.70 m) gradual, a distinct layer of mollusc remains $(13.82-13.85 \mathrm{~m})$

14.02-20.73 2 Glaciolacustrine clayey silt: topmost part (14.02-14.65 m) homogenous, probably reworked beige varved clay, from $14.65 \mathrm{~m}$ brownish-grey varved clay

Pe-3

$0.00-8.20 \quad$ Water

$8.20-10.55 \quad 5 \quad$ Gyttja

10.55-10.85 4 Lake marl: homogenous, light bluish-grey, contains mollusc remains on the transition from the sand

10.85-11.00 3 Sand: brownish, fine-grained, lower boundary very sharp and erosional, transition to lake marl gradual, in the upper part mollusc remains

11.00-14.72 2 Glaciolacustrine varved clay: brownish-grey, at $11.00-11.90 \mathrm{~m}$ contains 15 varves, $11.90-13.50 \mathrm{~m}$ homogenous with traces of postsedimentational slides, $13.50-14.72 \mathrm{~m}$ contains 20 clearly proximal varves

14.72-15.50 1 Till: brownish-grey loamy till with pebbles

(Fig. 6). The $\mathrm{CaCO}_{3}$ content rises in this part over $50 \%$, while the content of organic matter remains below 10\% (Fig. 7). According to the lithological classification of the organic and calcareous lake deposits of Estonia (Saarse 1990), this interval could be considered as lake marl. The variable grain-size composition of lake marl is characterized by the increasing (from 35 to 50\%) upwards content of clay particles. Two levels (c. 12.30 and $13.00 \mathrm{~m}$ ) with a relatively higher 


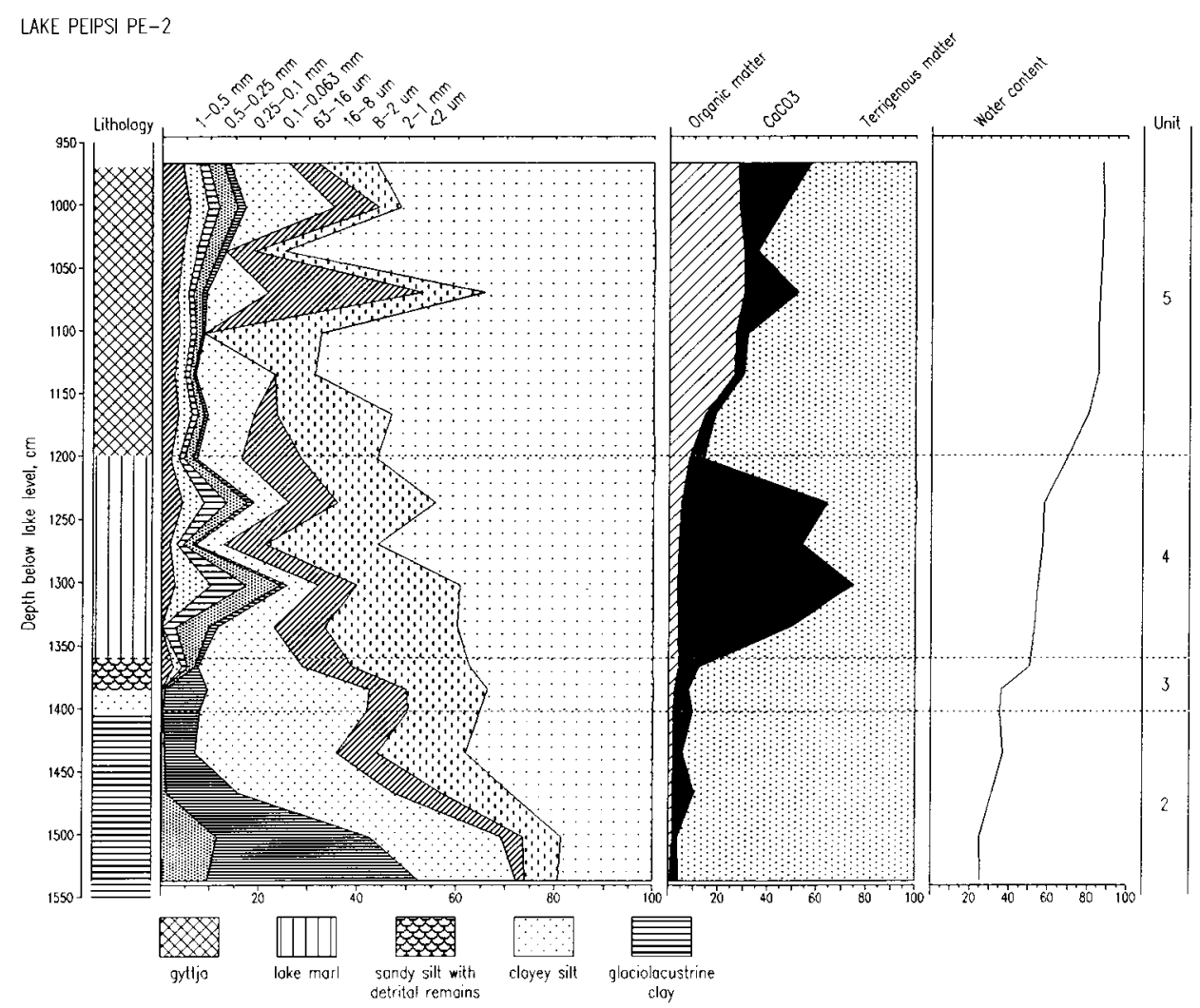

Fig. 7. Grain-size distribution, loss-on-ignition, and water content in the sediments of the sequence Pe-2. See Fig. 1 for the location of the site.

content of fine sand correlative with the higher $\mathrm{CaCO}_{3}$ content (Fig. 7) could be mentioned. The lowermost portion of lake marl contains remains of mollusc shells, while in the entire interval ostracods are common (Niinemets 1999).

The transition from the lake marl to the overlying greenish gyttja is gradual. The change in colour takes place within $20-30 \mathrm{~cm}$. The $\mathrm{CaCO}_{3}$ content in the sequence Pe-2 changes rapidly at about $12.25 \mathrm{~m}$ b.l.1. (Fig. 7). Between 12.00 and $11.00 \mathrm{~m}$, the $\mathrm{CaCO}_{3}$ content remains below $10 \%$, while the content of organic matter is increasing from about $10 \%$ to c. $35 \%$. According to the classification of lake deposits (Saarse 1990), this interval could be treated as silicic gyttja. The increasing carbonate content and the following decrease in terrigenous matter allow us to classify the uppermost portion of the investigated part of the sequence Pe-2 (Fig. 7) as calcareous silicic gyttja.

The youngest, topmost part of organic lacustrine deposits is represented by dark brown or black loose gyttja. Very thin and scattered distribution of these deposits is recorded in the areas shallower than $9 \mathrm{~m}$ of water depth, but in the northern, and especially western part of the distribution area, their thickness 
increases very rapidly up to $3 \mathrm{~m}$ (Fig. 5). In the central, deepest part of the lake these deposits are mainly $4 \mathrm{~m}$ thick, reaching in places up to $6 \mathrm{~m}$ (Fig. 5).

\section{Pollen stratigraphy}

Pollen analyses were carried out from the sediment core Pe-2 (Fig. 1). The lithology of the investigated interval (11.90-14.20 m) is described in Table 1. The topmost part of the sequence (Table 1) was not studied. The pollen diagram (Fig. 8) is divided into four local pollen assemblage zones (Pe 1-Pe 4).

\section{Pe $1(1415-1400 \mathrm{~cm})$}

The proportion of nonarboreal pollen (NAP) is remarkably high, forming 35$55 \%$ of pollen sum. Artemisia and Chenopodiaceae with maximum values (respectively up to 20 and 5-10\%) and also Poaceae and Cyperaceae dominate within NAP.

Arboreal pollen (AP) is represented mainly by Betula. As the pollen grains were highly corroded and distorted, correct identification of different species was impossible. Pinus has low values. Single pollen grains of Picea were registered. Salix, Juniperus, and Populus show permanent curves. The corroded pollen grains of Alnus and Corylus are probably redeposited.

Pediastrum is low (1-3\%), rising at the upper border of the zone.

\section{Pe $2(1400-1360 \mathrm{~cm})$}

Nonarboreal pollen decreases towards the upper zone border (from 40 to $17 \%$ ), but is still present in high proportions. It is represented mainly by Cyperaceae and Poaceae, reaching their maximum, and Artemisia and Chenopodiaceae. Ericales (most probably Empetrum) has a continuous curve with a small peak. Aquatics (Typha latifolia, Stratiotes aloides) are present occasionally. A single pollen grain of Ephedra and that of Dryas octopetala were found.

Betula and Pinus dominate in AP. Betula rises towards the upper zone limit. The permanent presence of Picea is remarkable. Juniperus and Salix culminate in this pollen zone. Populus has a continuous curve. Few distorted pollen grains of Alnus and Corylus were found.

Pediastrum culminates in this zone (10-20\%).

The pollen zones Pe 1 and Pe 2 can be correlated with the Younger Dryas Chronozone (Mangerud et al. 1974).

\section{Pe 3 (1360-1220 cm)}

The AP, represented mainly by Betula and Pinus, dominates. Nonarboreal pollen forms only 4-9\%. Alnus and Picea disappear in the middle of the zone and Corylus and Ulmus are present in low values. The proportion of Salix and Polypodiaceae (mainly Polypodium vulgare) is relatively high. Salix decreases evenly upwards in the zone. Aquatics are practically lacking.

This zone ranges into the Preboreal Chronozone (Mangerud et al. 1974). 


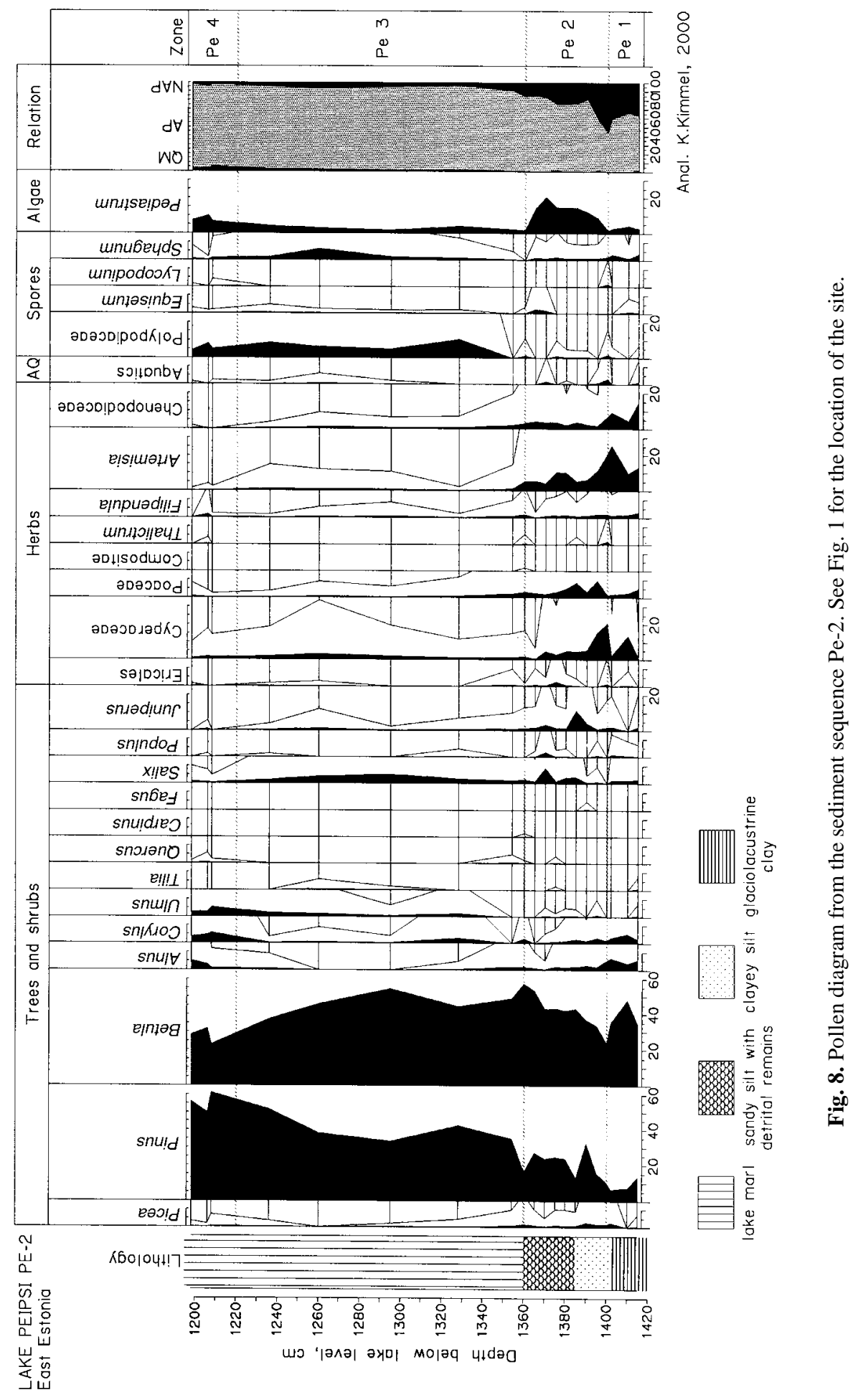




\section{Pe $4(1220-1198 \mathrm{~cm})$}

Pinus dominates, with Betula being subdominant. A rise of Alnus, Corylus, and Ulmus is characteristic of the lower portion of the zone. The zone can be correlated with the beginning of the Boreal Chronozone (BO1).

\section{DISCUSSION}

Generally good accordance between seismic and coring data with minor discrepancies could be stressed. The ridge-like form (Fig. 3) in the northern part of the investigated area cannot be followed on the map of till topography (Fig. 2B). Vice versa, the map displays a surprisingly low altitude of the till surface east of the Sahmen Shallow (Fig. 2B), which could be explained with the position and orientation of the seismic profiles. During the profiling it turned impossible to run the vessel in relatively shallow water areas (surroundings of the Sahmen Shallow). Therefore, as the east-west oriented profiles run parallel to the ridge, the computer generated map of the till surface could easily contain minor misinterpolations.

The genesis of the suggested ridge-like formation is complicated to explain. According to the southwest-northeast orientation of the ridge, it could be interpreted as an ice-marginal formation formed during a short standstill or smaller readvance in the course of ice recession during the Late Weichselian. But mostly this ridge is buried under glaciolacustrine varved deposits (Fig. 3) with only its higher parts outcropping in the lake bottom. Moreover, the sequences of glaciolacustrine varved clays from both, proximal and distal sides of the ridge, as well as from the top, are easy to correlate varve by varve. Therefore, it should be concluded that the ridge was formed either before the final ice recession or under the ice. Otherwise, we could expect a couple of dozen varves more on the distal (southern) side of the ridge.

There is a strong evidence suggesting some misinterpretations from the seismic profiles in the southern part of the lake. Corings on the southwest-northeast oriented profile offshore from Varnja (Fig. 1) gave no sign of glaciolacustrine clays, which according to seismic interpretations should have covered the till as a 10-13 m thick layer (Fig. 2C). About $10 \mathrm{~km}$ offshore (sites 16, 17 in Fig. 1) a layer of buried organic matter was discovered under the sand (Fig. 3). It was heavily compressed peat with a thickness of up to $80 \mathrm{~cm}$. With the coring and even sonding equipment we could not reach the sediments lying below these organic deposits, and thus the existence of very compact sediments, most likely till, was suggested. Therefore, the reinterpretation of seismic profiles from the area would be necessary, especially when more corings will be added.

Differences in varve character between laminated glaciolacustrine deposits in the northern and central parts of the lake point to different sedimentation environments. In our opinion, unstable laminations in the central part could be interpreted as rhythmites deposited in a relatively shallow water basin with 
changing sediment supply from the catchment rather than glacial annual varves. Varved clays, correlative to those in the northern part of the lake, were probably not reached in the central part. This conclusion is supported by seismic data, which suggests c. 10 more metres of glaciolacustrine deposits than discovered by corings. Also, an erosional character of the upper boundary of varved sequences in the northern part of the lake shows that the uppermost laminated deposits, correlative to those discovered in the central part, have not been deposited there at all or have been eroded due to wave-wash.

The water level and configuration of the proglacial lakes in the L. Peipsi depression was controlled by the stepwise retreat of the Late Weichselian ice and has been reconstructed by geomorphological evidences (Raukas \& Rähni 1969). Dating of different events causing water level changes has been very complicated and is still unconvincing. So its not convincingly dated when the ice started to retreat from the belt of ice-marginal formations in the southernmost part of L. Peipsi (Piirissaar glaciofluvial delta) and when the whole area of the recent lake was finally deglaciated. North of the L. Peipsi depression, the PandivereNeva stage is marked by the Männikvälja-lisaku ice-marginal formations, which are dated back to 12050 BP (Raukas et al. 1971; Raukas \& Kajak 1997). The date is obviously too young compared to the age of the well-known Younger Dryas ice-marginal formations (10 $\left.300{ }^{14} \mathrm{C} \mathrm{BP}\right)$ in southern Finland. According to varve chronology, the age of the Second Salpausselkä formations is 10643 varve yr BP and of the First Salpausselkä formations, 11143 varve yr BP (Strömberg 1990; Hang 1997). Both of these ages should be revised if the missing 875 years were added to the Swedish Time Scale (STS) (Andrén et al. 1999). Hang (1997), comparing varve chronological data from northeastern Estonia and northwestern Russia with the STS, ended up with the age of about 12330 varve yr BP for the Pandivere-Neva formations, which also should be taken with caution because of the mentioned above possibility of missing years in the STS. Recently, Saarnisto \& Saarinen (2001) obtained similar dates. On the basis of varved clays and AMS radiocarbon dates from northwestern Russia, they suggested the age of 13300 calendar years ago for the Pandivere-Neva Formation. Thus, we can conclude that at least 13300 calendar years ago the recent L. Peipsi area was already deglaciated.

The duration of deglaciation from the surroundings of Piirissaar Island to the northern coast of the lake is still under discussion. According to the number of varves in the clay varve sequences north of the lake, Rähni (1963) concluded that the deglaciation of the lake lasted 250-280 years. Varve chronology, established in the course of the present study from the northern part of the lake, contains 370 years, pointing to the minimum duration of proglacial conditions in this part of the lake, but it does not tell much about the southern part of the investigated area where the glaciolacustrine varved clays are most likely missing. In the case of similar ice recession rates in the southern and northern parts of the lake we could expect at least 500-700 years for the deglaciation of the whole considered part of the lake depression. 
After the retreat of the Weichselian inland ice into the Gulf of Finland, the water level dropped and the Peipsi basin isolated from the proglacial lake. It has been postulated that $\mathrm{L}$. Peipsi isolated when the water level in the Baltic Ice Lake dropped from $B_{1}$ to $B_{111}$ level prior to the final drainage. Obviously, the area of the proglacial basin grew considerably, causing gradual rather than catastrophic lowering of lake level. This could be considered as the initial stage of the low water level period, so-called Lake Small Peipsi. The final drainage of the Baltic Ice Lake at 11565 calibrated years BP, equivalent to 10690 varve yr BP (Björck 1999), caused the lowering of the groundwater table and lake level in the L. Peipsi basin. The water level reached its lowest level at the end of the Younger Dryas Chronozone. Geomorphological and biostratigraphical evidence from the mouth of the Emajõgi River (Sarv \& Ilves 1975) demonstrate up to $6 \mathrm{~m}$ lower water level than in the southern part of the investigated area at the beginning of the Preboreal. However, according to recent data on litho- and biostratigraphy of the bottom deposits of L. Peipsi, the water level at that time was at least $10 \mathrm{~m}$ lower. An argument for such a conclusion is the distribution of Holocene organicrich lacustrine deposits, which is limited to the area of the water depth of more than $9 \mathrm{~m}$ (in the northern part of the lake more than $10 \mathrm{~m}$ ). We think that this area approximately coincides with that of L. Small Peipsi (Fig. 5). Outside this limit, the wave-wash accompanying the lake level rise which followed the L. Small Peipsi stage, turned the accumulation of gyttja impossible. The at least $10 \mathrm{~m}$ lower water level during the L. Small Peipsi stage is also supported by the sandy mollusc-rich offshore sediments accumulated during the transition from the Younger Dryas to the Preboreal (Fig. 8). Closer to the coastal areas (sites 2, 3; Figs. 6, 7), the transition from glaciolacustrine clay to sand carries erosional character, demonstrating that the wave-wash has reached the bottom. The altitude of this erosional level is 11-14 $\mathrm{m}$ b.l.l. Moreover, because of the possible hiatus we can expect the water level in L. Small Peipsi even lower than $10 \mathrm{~m}$ below recent lake level. Thus the configuration and the water level of L. Small Peipsi, presented here, differs from earlier suggestions where even the present coastal areas north of the lake were flooded (Raukas \& Rähni 1969). If the concept of the lower water level holds true, we may conclude that the southern and the northern parts of the recent lake bottom were not covered by the water and remained as wetlands. As the minimum altitude of the till surface in the southern part of the investigated area (surroundings of Piirissaar Island) hardly drops down to $20 \mathrm{~m}$ a.s.l. and the suggested water level of L. Small Peipsi was also about $20 \mathrm{~m}$ a.s.l., the isolation of L. Small Peipsi from the water bodies south of it (in the southern part of the lake depression) may be assumed.

Lake marl accumulated in Preboreal Lake Peipsi. According to pollen evidence (Fig. 8), the accumulation of calcareous deposits started already at the end of the Pe 2 pollen zone, which could be correlated with the Younger Dryas Chronozone. Calcareous sandy deposits rich in mollusc remains (Fig. 8) mark the transition from the L. Small Peipsi stage to Preboreal L. Peipsi. Due to low lake level at the end of the Younger Dryas the activity of waves could easily reach the bottom 
while the Younger Dryas-Preboreal boundary is transitional and difficult to identify. The abundance of ostracod fauna starts also from this stratigraphical level. According to Niinemets (1999), the ostracod fauna demonstrates the groundwater feeding of the shallow and cold body of water during that period. The presence of Ilyocypris bradyi and Herpetocypris reptans refers to the water depth around $4 \mathrm{~m}$. The altitude of the lower surface of lake marl in the deeper part of the lake determined within the present study is around 16-17 m (Fig. 3). If the assumption of the water depth around $4 \mathrm{~m}$ holds true, the lake level at the beginning of the Preboreal Lake Peipsi could have been approximately $20 \mathrm{~m}$ a.s.l., which is c. $10 \mathrm{~m}$ lower than at present (Fig. 6). Thus, as the lake level was rather similar to the level of L. Small Peipsi, the distribution of the lake was also limited to the deeper, central part of the depression, as demonstrated in Fig. 5. According to ostracod evidence, rather similar shallow water conditions prevailed through the entire interval (up to $2 \mathrm{~m}$ ) of marl accumulation, pointing in a way to the slow water level rise. The marl accumulation most likely terminated during the Pe 4 pollen zone, which was correlated with the beginning of the Boreal (BO1) Chronozone (Fig. 8).

The accumulation of lacustrine and fluvial deposits started in different parts of the lake basin from the Boreal Chronozone, demonstrating a water level rise. Due to uneven crustal rebound, it started earlier in the areas south of the investigated part (Miidel et al. 1995). In the surroundings of the mouth of the Emajõgi River (southern part of the area under discussion), the water level rise is recorded from the second half of the Atlantic Chronozone. According to diatom evidence from the site of L. Lämmijärv (Davydova \& Kimmel 1991), it was not until the Subboreal Chronozone that L. Peipsi joined with the body of water south of the area considered (Hang \& Miidel 1999b). Due to wave-wash in the surroundings of Piirissaar Island in the course of the water level rise, sandy deposits were accumulating in the southern part of the investigated area (Figs. 3, 5). A layer of buried peat covered with 1.5-2 $\mathrm{m}$ of lacustrine sand was found in the southern part of the lake 7-11 km offshore (sites 16, 17; Figs. 1, 3). Preliminary data from the pollen record demonstrates the Preboreal age of the peat, supporting therefore the currently concluded low water level at the beginning of the Preboreal Lake Peipsi stage.

The Early Holocene water level changes close to the present north coast of L. Peipsi are still under discussion. It has been supposed that as long as until the Atlantic Chronozone the waters of L. Small Peipsi flooded the area NNW of the present coast, having the water level 5-6 $\mathrm{m}$ higher than at present (Miidel et al. 1975). This supposition is very hard to adjust to the data of the current research. So it is difficult to explain why Holocene lacustrine deposits are lacking in the northern offshore area of the lake (Figs. 3, 5). If at the beginning of the Holocene the lake was several metres deeper than at present, these deposits ought to exist there, because in similar conditions in the central part of the lake they are up to $6 \mathrm{~m}$ thick. According to our lithological data it is more obvious to suggest a water level rise instead of deep-water conditions. During the low water level stage 
(Preboreal L. Peipsi) at the beginning of the Holocene, when the lake marl was accumulating in the deeper, central part of the lake, the northern part of the recent lake was most likely dry or wetland. Probably the wave-wash turned the accumulation of gyttja impossible during the following slow water level rise. In a way this is supported by the lack of the upper portion of varved clays in the area resulting from the abrasion.

\section{CONCLUSIONS}

1. In the northern part of the investigated area (Fig. 1) seismic stratigraphy (Noormets et al. 1998) correlates well with the coring data. In the southern part of the lake glaciolacustrine varved clay was not distinguished within the corings (Fig. 3). At the same time, an up to $13 \mathrm{~m}$ thick layer of varved clays was recorded from the seismic profiles (Fig. 2C). Additional mapping of bottom deposits in the area is recommended to confirm the misinterpretation from seismoacoustic profiles.

2. Data from the echosounder profiles supported by the coring data allow us to outline the distribution and the thickness of lake marl and organic gyttja deposits in the lake (Fig. 5).

3. The L. Peipsi depression deglaciated before the development of the Pandivere-Neva ice-marginal formations 13300 calendar years ago (Saarnisto \& Saarinen 2001). It is supposed that deglaciation from the Piirissaar glaciofluvial delta to the north coast of the recent lake lasted 500-700 years.

4. Lowering of water level in the depression of L. Peipsi started during the Younger Dryas. Lake Peipsi isolated from the proglacial lake before the final drainage of the Baltic Ice Lake and reached its minimum already at the end of the Younger Dryas.

5. The water level of the L. Small Peipsi stage was at least $10 \mathrm{~m}$ lower (c. $20 \mathrm{~m}$ a.s.l.) than at present ( $30 \mathrm{~m}$ a.s.l.).

6. According to lithological data, the configuration of L. Small Peipsi and the Preboreal L. Peipsi coincides approximately with the contours of the distribution of gyttja deposits in the lake (Fig. 5). Thus the northern and the southern part of the lake were not covered by water and probably remained dry or in places as a wetland. The lake had no connection with the water bodies south of the investigated area.

7. The accumulation of calcareous deposits started at the transition from the Younger Dryas to the Preboreal. Deposition of lake marl started during the Preboreal Chronozone (Fig. 8) and completed during the first half of the Boreal Chronozone. According to ostracod evidence (Niinemets 1999), the Preboreal L. Peipsi was a groundwater feeded shallow and cold body of water with the water-depth around $4 \mathrm{~m}$ through the entire interval.

8 . Further research is required to understand the development of the northern part of the investigated lake area, which probably cannot be explained without considering the glacioisostatic rebound. 


\section{ACKNOWLEDGEMENTS}

This paper was derived from the projects supported by the grants Nos. 324 and 2059 of the Estonian Science Foundation (A. Miidel), Helge Ax:son Johnsons Stiftelse, the Swedish Society of Anthropology and Geography, Stiftelsen Längmanska Kulturfonden, and the Geological Survey of Finland. Timo Saarinen, Jüri Vassiljev, Kalle Kirsimäe, Valdo Kuusemets, Ain Kull, Mihkel Hang, and students from the University of Tartu assisted during the fieldwork. Arvi Järvekülg determined the molluscs. Kersti Kihno helped with the pollen diagram and the corings. Külli Kübar helped with the preparation of pollen samples. Many valuable and constructive comments were made by Urve Miller and Leili Saarse. The English text was revised by Helle Kukk. We sincerely thank these organizations and people for support and help.

\section{REFERENCES}

Andrén, T., Björck, J. \& Johnsen, S. 1999. Correlation of Swedish glacial varves with the Greenland (GRIP) oxygen isotope record. J. Quat. Sci., 14, 361-371.

Berglund, B. E. \& Ralska-Jasiewiczowa, M. 1986. Pollen analysis and pollen diagrams. In Handbook of Holocene Palaeoecology and Palaeohydrology (Berglund, B. E., ed.), pp. 455-484. John Wiley \& Sons, Chichester.

Björck, J. 1999. Event stratigraphy for the Last Glacial-Holocene transition in eastern middle Sweden. Quaternaria A, 6.

Blakemore, L. C., Searle, P. L. \& Daly, B. K. 1987. Methods of chemical analysis of soils. New Zealand Soil Bur. Sci. Rep., 80.

Davydova, N. \& Kimmel, K. 1991. Palaeogeography of L. Peipsi on the basis of biostratigraphical studies of bottom sediments. Proc. Estonian Acad. Sci. Geol., 40, 16-23 (in Russian).

Grimm, E. C. 1992. TILIA and TILIA GRAPH: Pollen spreadsheet and graphics program. In 8 th International Palynological Congress. Program and Abstracts, p. 56. Aix-en-Provence, France.

Hang, T. 1997. Clay-varve chronology in the Eastern Baltic area. GFF, 119, 295-300.

Hang, T. \& Miidel, A. 1999a. Lake deposits. Thickness and structure. In Lake Peipsi: Geology (Miidel, A. \& Raukas, A., eds.), pp. 59-61. Sulemees Publ., Tallinn.

Hang, T. \& Miidel, A. 1999b. Holocene history of the lake. In Lake Peipsi: Geology (Miidel, A. \& Raukas, A., eds.), pp. 131-135. Sulemees Publ., Tallinn.

Kajak, K. 1964. Peipsi nõo geoloogiast ja geomorfoloogiast. In Eesti Geograafia Seltsi aastaraamat 1963 (Hang, E. \& Tarmisto, V., eds.), pp. 20-33. Eesti NSV Tead. Akad., Tallinn.

Mangerud, J., Andersen, S. T., Berglund, B. E. \& Donner, J. J. 1974. Quaternary stratigraphy of Norden, a proposal for terminology and classification. Boreas, 3, 109-128.

Miidel, A., Pirrus, R., Raukas, A. \& Rähni, E. 1975. Main features of the development of the PeipsiPihkva Lake basin. In Istoriya ozer $v$ golotsene: IV Vsesoyuznyi simpozium po istorii ozer, Tezisy dokl., 3 (Kvasov, D. D. \& Jakushko, O. F., eds.), pp. 50-55. Leningrad (in Russian).

Miidel, A., Hang, T., Pirrus, R. \& Liiva, A. 1995. On the development of the southern part of Lake Peipsi in the Holocene. Proc. Estonian Acad. Sci. Geol., 44, 33-44.

Miidel, A., Noormets, R., Hang, T., Flodén, T. \& Bjerkéus, M. 2001. Bedrock geology and topography of the Lake Peipsi depression, eastern Estonia. GFF, 123, 15-22.

Niinemets, E. 1999. Ostracods. In Lake Peipsi: Geology (Miidel, A. \& Raukas, A., eds.), pp. 90-97. Sulemees Publ., Tallinn. 
Noormets, R., Hang, T., Miidel, A., Flodén, T. \& Bjerkéus, M. 1998. Seismic stratigraphy of Quaternary deposits in Lake Peipsi, eastern Estonia. GFF, 120, 47-52.

Pirrus, R. 1981. Characteristics of pollen and spore spectra of the upper layer of bottom sediments in Lake Pihkva-Peipsi. In Donnye otlozheniya Pskovsko-Chudskogo ozera (Raukas, A., ed.), pp. 42-55. AN ÉSSR, Tallinn (in Russian).

Raukas, A. 1981. On the lithological composition of bottom deposits in Lake Pihkva-Peipsi. In Donnye otlozheniya Pskovsko-Chudskogo ozera (Raukas, A., ed.), pp. 23-41. AN ÉSSR, Tallinn (in Russian).

Raukas, A. \& Kajak, K. 1997. Stratigraphy of the Late-glacial deposits. In Geology and Mineral Resources of Estonia (Raukas, A. \& Teedumäe, A., eds.), pp.134-135. Estonian Acad. Publ., Tallinn.

Raukas, A. \& Rähni, E. 1969. On the geological development of the Peipsi-Pihkva depression and the basins distributed in that region. ENSV TA Toim. Keemia Geol., 18, 113-127 (in Russian).

Raukas, A. \& Rähni, E. 1981. Structural types of Pihkva-Peipsi bottom sediments and the peculiarities of their formation. In Donnye otlozheniya Pskovsko-Chudskogo ozera (Raukas, A., ed.), pp. 7-22. AN ÉSSR, Tallinn (in Russian).

Raukas, A., Rähni, E. \& Miidel, A. 1971. Marginal Glacial Formations in North Estonia. Valgus, Tallinn (in Russian).

Rähni, E. 1963. On the geochronology of north-east Estonian varved clays. Eesti NSV Geol. Inst. Uurim., 12, 81-94 (in Russian).

Saarnisto, M. \& Saarinen, T. 2001. Deglaciation chronology of the Scandinavian ice sheet from the Lake Onega basin to the Salpausselkä end moraines. Global Planet. Change (in print).

Saarse, L. 1990. Classification of lake basins and lacustrine deposits of Estonia. J. Paleolimn., 3, $1-12$.

Sarv, A. \& Ilves, E. 1975. Über das Alter der holozänen Ablagerungen im Mündungsgebiet des Flusses Emajõgi (Saviku). Proc. Estonian Acad. Sci. Chem. Geol., 24, $64-69$ (in Russian).

Strömberg, B. 1990. A connection between the clay varve chronologies in Sweden and Finland. Ann. Acad. Sci. Fennicae, A.11l, 6-33.

Valt, E. 1976. Aruanne liiva ja kruusa otsimistööde tulemustest Peipsi järve piirkonnas. Manuscript, Geol. Survey Estonian SSR, Keila.

\section{UUSI ANDMEID PEIPSI JÄRVE PÕHJASETETE LEVIKU JA STRATIGRAAFIA KOHTA}

Tiit HANG, Avo MIIDEL, Volli KALM ja Kai KIMMEL

Viirsavide uurimisel selgus, et järve põhjaosas kestis nende settimine vähemalt 370 aastat. Oletatakse, et järvenõo vabanemiseks liustiku alt Piirissaare glatsiofluviaalsest deltast järve põhjarannikuni kulus mitte vähem kui 500-700 aastat. Kajaloodimis- ja puurimisandmetel koostati järvelubja ja sapropeeli levikuskeem, mis üldjoontes näitab järve ulatust hilisdrüüases (Väike-Peipsi) ja preboreaalis (preboreaalne Peipsi). Praeguse järve põhja- ja lõunaosa (Piirissaarest põhja pool) oli sel ajal kuiv. Hilisdrüüases tekkinud Väike-Peipsi veetase oli $10 \mathrm{~m}$ madalamal praegusest ka veel preboreaali alguses. Hilisdrüüase lõpul algas Väike-Peipsis järvelubja settimine, mis kestis boreaali esimese pooleni. Aeglaselt kerkiva veetasemega järv oli külmaveeline ja madal (sügavus veidi üle $4 \mathrm{~m})$. 


\title{
НОВЫЕ ДАННЫЕ ПО РАСПРОСТРАНЕНИЮ И СТРАТИГРАФИИ ДОННЫХ ОТЛОЖЕНИЙ ЧУДСКОГО ОЗЕРА, ВОСТОЧНАЯ ЭСТОНИЯ
}

\author{
Тийт ХАНГ, Аво МИЙДЕЛ, Волли КАЛМ и Кай КИММЕЛ
}

\begin{abstract}
Хронология слоев ленточных глин в северной части Чудского озера насчитывает 370 лет. Предполагается, что отступание ледника от Пийриссаареской флювиогляциальной дельты до северного побережья продолжалось не менее 500-700 лет. По данным буровых работ и эхолотирования составлена схема распространения сапропелевых и карбонатных (озерный мергель) отложений, покрывающих приблизительно контуры Малого Пейпси, возникшего в молодом дриасе, и пребореального Пейпси. Северную и южную части озерной впадины (севернее о-ва Пийриссаар) в то время занимала суша. Уровень Малого Пейпси был на 10 м ниже современного и в начале пребореала. В конце молодого дриаса началось накопление озерного мергеля, продолжавшееся до первой половины бореала. Озеро с медленно поднимающимся уровнем воды было холодно- и мелководным (глубина немногим более 4 м).
\end{abstract}

